\title{
ANALISIS TINGKAT KEPUASAN TERHADAP WEBINAR PENDIDIKAN SEBAGAI SARANA PENINGKATAN KREATIVITAS GURU DI ERA NEW NORMAL
}

\author{
Alifia Nurul Hasanah ${ }^{* 1}$, Fathiyyah Husna Sulaiman ${ }^{1}$, Putri Lidya Sari ${ }^{1}$, Grace Natalia ${ }^{1}$, \\ Febyana Nur Aliffah $^{1}$, Iwan Sugihartono ${ }^{* 1}$, Erfan Handoko ${ }^{1}$, Sarkadi $^{2}$, Yayat W. \\ Heriyanto $^{3}$, Achmad Ainul Yaqin ${ }^{4}$, Jack Luhukay ${ }^{5}$ \\ ${ }^{1}$ Program Studi Fisika, FMIPA Universitas Negeri Jakarta, Jl. Rawamangun Muka, \\ Jakarta Timur 13220, Indonesia \\ ${ }^{2}$ Program Studi Pendidikan Pancasila dan Kewarganegaraan, FMIPA Universitas \\ Negeri Jakarta, Jl. Rawamangun Muka, Jakarta Timur 13220, Indonesia \\ ${ }^{3}$ Yayasan Pondok Karya Pembangunan DKI Jakarta, Jalan Raya PKP Kelapa \\ Dua Wetan Ciracas, Jakarta Timur 13730, Indonesia \\ ${ }^{4}$ FMIPA Universitas Negeri Jakarta, Jl. Rawamangun Muka, Jakarta Timur 13220, \\ Indonesia \\ ${ }^{5} \mathrm{CV}$ Jyotis Cemerlang, Bekasi, Indonesia \\ Email : alifianurulhasanah26@gmail.com,iwan-sugihartono@unj.ac.id
}

\begin{abstract}
During the Covid-19 pandemic, the transition from the PSBB period to the new normal era still had a significant impact in various sectors, mainly the education sector of teaching and learning activities. Online learning that is held provides a challenge to the creativity of teachers. For this reason, KKN's team of State University of Jakarta held an educational webinar with the theme 'Online Learning Trends in the New Normal Era' to enlighten teachers to be creative in improving teaching skills in order to establish students' character. From the feedback form given to the webinar participants, data processing and analysis have been carried out to elaborate the teacher's enthusiasm for teaching creativity to improve student character with educational webinars. This research uses a quantitative descriptive method by questionnaires as a data collection technique, including the theme, the agenda, the speakers presented, and the persistence in each session of the webinar. In general, the respondents gave positive responses indicating the level of satisfaction of the participants. In conclusion, the teacher agreed that creativity in learning was able to build the character of students.
\end{abstract}

Keywords: era new normal; teacher creativity; educational webinars; quantitative descriptive; level of satisfaction

\begin{abstract}
Abstrak
Pada masa pandemi Covid-19, beralihnya masa PSBB menjadi era new normal masih memberikan dampak yang signifikan di berbagai sektor, terutama sektor pendidikan dalam pelaksanaan kegiatan belajar mengajar. Proses pembelajaran secara daring yang diselenggarakan memberikan tantangan terhadap kreativitas guru dalam kegiatan belajar mengajar. Oleh karena itu, Tim KKN Universitas Negeri Jakarta mengadakan webinar pendidikan dengan tema 'Trend Pembelajaran Daring di Era New Normal' untuk memberikan pencerahan bagaimana guru dapat berkreasi meningkatkan kemampuan mengajar agar karakter siswa dapat terbentuk. Melalui form feedback yang diberikan kepada para peserta webinar, telah dilakukan pengolahan data dan analisis untuk mengelaborasi
\end{abstract}


antusiasme guru pada kreativitas mengajar untuk meningkatkan karakter siswa melalui webinar pendidikan. Penelitian ini menggunakan metode pendekatan deskriptif kuantitafif melalui kuesioner sebagai teknik pengumpulan data, meliputi tema webinar, susunan acara webinar, narasumber yang dihadirkan, dan keberlangsungan acara webinar di setiap sesinya. Secara keseluruhan responden memberikan respon positif yang menandakan tingkat kepuasan peserta, dalam hal ini guru setuju terhadap kreativitas dalam pembelajaran mampu membangun karakter siswa.

Kata Kunci: Era new normal, kreativitas guru, webinar pendidikan, deskriptif kuantitatif, tingkat kepuasan

\section{PENDAHULUAN}

Masa pandemi Covid-19 memberikan dampak yang signifikan pada peradaban manusia. Sejak ditetapkannya pembatasan sosial berskala besar (PSBB) dalam rangka penanganan Covid-19, seluruh aspek kehidupan masyarakat telah berubah. Masyarakat diharapkan dapat menerapkan protokol kesehatan untuk mencegah penyebaran virus Covid-19. Pada 1 Juni 2020, pemerintah telah menetapkan adanya transisi masa PSBB menjadi era new normal (Unicef, 2020).

Pada era new normal, World Health Organization (WHO) memberikan beberapa indikator untuk dipatuhi oleh negara-negara di seluruh dunia demi menyesuaikan kehidupan normalnya. Bertepatan dengan hal tersebut, Satgas penanganan COVID-19 mengeluarkan Surat Edaran (SE) Nomor 16 Tahun 2021 disampaikan bahwa setiap individu wajib menerapkan protokol kesehatan yang meliputi memakai masker, mencuci tangan dengan sabun di air mengalir, menjaga jarak, menjauhi kerumunan, mengurangi mobilitas, dan menghindari makan bersama $(6 \mathrm{M})$.

Meskipun telah menerapkan protokol kesehatan, era new normal masih memberikan dampak di berbagai sektor, terutama sektor pendidikan dalam pelaksanaan kegiatan belajar mengajar. Pendidikan merupakan kontribusi terbesar perkembangan sumber daya manusia, khususnya dalam pembangunan bangsa dan negara. Menyikapi hal tersebut, agar sektor pendidikan berjalan dengan baik di masa pandemi melalui daring, perlu dilakukannya proses adaptasi antara tenaga pengajar, peserta didik dan teknologi (Syariffudin, 2020).

Proses belajar konvensional dalam bentuk tatap muka menjadi tidak mungkin untuk dilakukan karena kekhawatiran terjadinya penularan virus tersebut, sehingga proses pembelajaran dilakukan dalam bentuk daring (dalam jaringan). Kegiatan belajar mengajar secara daring tentunya merupakan hal baru yang menjadikannya tantangan di dalam dunia pendidikan (Hatip, 2020; Siagian, 2020).

Sebagian besar guru hanya menggunakan metode mengajar yang monoton, sehingga menyebabkan antusiasme siswa berkurang. Oleh karena itu, guru dituntut aktif dan kreatif dalam menyampaikan materi pembelajaran agar suasana belajar yang kondusif dan menyenangkan 
terwujud (Pentury, 2017).

Melihat pembelajaran daring yang menimbulkan banyak kendala dari berbagai perspektif, kelompok pengabdian kepada masyarakat terintegrasi Kuliah Kerja nyata (KKN) yang dibimbing oleh Dr. Iwan Sugihartono dosen Program Studi Fisika FMIPA dan Sekretaris Lembaga Penelitian dan Pengabdian kepada Masyarakat (LPPM) Universitas Negeri Jakarta bekerja sama dengan SMA PKP Jakarta Islamic School yang disponsori oleh CV Jyotis Cemerlang menyelenggarakan Webinar Pendidikan yang bertema "Trend Pembelajaran Daring di Era New Normal" pada Sabtu, 14 Agustus 2021, pukul 09.00-12.00 WIB. Dengan berlangsungnya acara tersebut, diharapkan dapat memberikan motivasi guru dalam meningkatkan kreativitas mengajar selama pembelajaran daring di era new normal guna pembentukan karakter siswa.

\section{TINJAUAN LITERATUR}

Pendidikan merupakan proses pembelajaran yang bertujuan untuk dikembangkannya bakat pada diri manusia, baik itu bersifat kepribadian, kecerdasan, spritual dan keagamaan (Juliya dan Herlambang, 2021). Selain itu, pendidikan juga dapat diartikan sebagai sebuah wadah yang sangat beharga untuk melakukan edukasi terhadap siswa dalam menciptakan pola pikir kritis, sehingga setiap siswa memiliki karakter kuat, bersahaja, dan bermanfaat secara luas baik di bidang sosial, masyarakat, dan pendidikan (Suriadi dkk., 2021).

$$
\text { Masa pandemi Covid-19 }
$$
memberikan dampak yang signifikan pada peradaban manusia, terutama pada sektor pendidikan. Sistem pembelajaran yang digunakan pada masa pandemi Covid-19 adalah sistem belajar online atau daring (Givan dkk, 2021). Kegiatan belajar mengajar secara daring menimbulkan banyak kendala dari berbagai perspektif, seperti yang dikutip dari Pusat Data Teknologi Informasi Kementrian Pendidikan dan Kebudayaan, Indonesia menghadapi beberapa tantangan nyata dalam pembelajaran daring: (1) ketimpangan teknologi antara sekolah di kota besar dan daerah, (2) keterbatasan kompetensi guru dalam pemanfaatan aplikasi pembelajaran, (3) keterbatasan sumberdaya untuk pemanfaatan teknologi Pendidikan seperti internet dan kuota, (4) relasi guru-murid-orang tua dalam pembelajaran daring yang belum integral. (Pusdatin Kemdikbud, 2020). Hal tersebut menyebabkan sebagian besar guru hanya menggunakan metode mengajar yang monoton, sehingga kurang dalam membangun karakter siswa dan menyebabkan antusiasme berkurang. Oleh karena itu, guru dituntut aktif dan kreatif dalam menyampaikan materi pembelajaran agar suasana belajar yang kondusif dan menyenangkan dapat terwujud (Pentury, 2017). Bedasarkan hal tersebut, pada prinsipnya pembelajaran daring memberikan tantangan tersendiri bagi kedua belah pihak, guru dan para siswa untuk mengembangkan potensi yang ada dalam 
dirinya (Winangun, 2020). Perumpaan yang dapat menggambarkan keterkaitan antara pembelajaran daring dan pembentukan karakteri siswa adalah "Online learning can present challenges to educators, because the tools and opportunities for discovering students' preconceptions and cultural perspectives are often limited by bandwidth constraints that limit the view of body language and paralinguistic clues" (Suriadi dkk., 2021).

Menyikapi hal tersebut, salah satu pilihan yang kini banyak digunakan oleh sebagian besar masyarakat Indonesia adalah metode webinar (Khairi, 2021). Metode tersebut dipilih sebagai upaya dalam peningkatkan tingkat kreativitas guru dalam pembelajaran daring. Webinar Pendidikan dengan tema 'Trend Pembelajaran Daring di Era New Normal' diharapkan dapat membantu guru dalam mengatasi permasalahan pembelajaran daring, meningkatkan kemampuan kreativitas siswa, dan menambah wawasan guru dalam pembelajaran daring serta pembentukan karakter siswa.

\section{METODE PELAKSANAAN}

Penelitian dalam jurnal ini menggunakan pendekatan deskriptif kuantitafif menggunakan kuesioner sebagai teknik pengumpulan data. Jenisuesioner yang digunakan adalah kuesioner tertutup. Instrumen kuesioner tertutup berisi pertanyaan mengenai pelaksanaan webinar pendidikan dan peserta webinar dapat menjawab dengan pilihan jawaban yang berupa skala kepuasan terhadap webinar.

Data penelitian diperoleh secara online dengan menggunakan google form. Subjek dalam penelitian ini adalah guru- guru di Yayasan PKP dan masyarakat umum yang berjumlah 129 orang. Kuesioner disebarkan dengan memanfaatkan room chat zoom clouds meeting saat proses pelaksanaan webinar berlangsung. Data yang diperoleh diolah dengan menggunakan Microsoft Excel yang kemudian dianalisis dengan rumus COUNTIF yang dikonversi menjadi bentuk persen untuk direpresentasikan dalam bentuk grafik. Grafik tersebut menggambarkan tingkat kepuasan dari acara tersebut sebesar 1-5. Skala 1 merepresentasikan tidak setuju dan skala 5 merepresentasikan sangat setuju yang diberikan oleh responden penelitian.

\section{HASIL DAN PEMBAHASAN}

Kegiatan webinar yang dilaksanakan pada hari Sabtu, 14 Agustus 2021 pukul 09.00-12.00 WIB merupakan suatu bentuk visualisasi antusiasme guru terhadap peningkatan kreativitas dalam kegiatan belajar mengajar di sekolah. Guru yang kreatif tentunya dapat menguasai materi yang disampaikan, dengan strategi penyampaian sertaketerampilan menggunakan berbagai macam media pembelajaran yang baik dan beragam. Selain kemampuan guru yang dituntut dalam pengembangan kreativitas, guru juga berperan penting dalam pembentukan karakter siswa. (Sulistiyorini dan M. Fathurrohman, 2016). Menyikapi hal tersebut, Webinar 
pendidikan yang dilaksanakan kegiatan pembuka pengabdian kepada masyarakat terintegrasi Kuliah Kerja Nyata (KKN) yang diselenggarakan oleh LPPM Univesitas Negeri Jakarta, dengan harapan mampu memberikan refleksi kepada para guru dalam meningkatkan kreativitas dan pembentukan karakter siswa. Terlihat antusiasme para guru terhadap peningkatan kreativitas mengajar dan pembentukan karakter siswa, tercermin dari kehadiran peserta yang melampaui target.

Webinar tersebut mampu menghadirkan 128 peserta dari kalangan guru dan mahasiswa umum. Terstukturnya acara merupakan salah satu hal penting yang menandakan acara berjalan dengan baik. Berikut merupakan hasil dari kuisioner yang diisi oleh responden sebagai tolak ukur penilaian keberlangsungan acara.

\section{Susunan Acara}

Gambar 1 adalah histogram dari respon peserta terhadap susunan acara yang berlangsung. Berdasarkan histogram pada gambar 1, peserta webinar menilai bahwa acara memiliki susunan acara yang terstruktur. Peserta juga memiliki impresi yang baik pada pembukaan acara yang dibuka oleh pimpinan dan alokasi waktu yang baik.

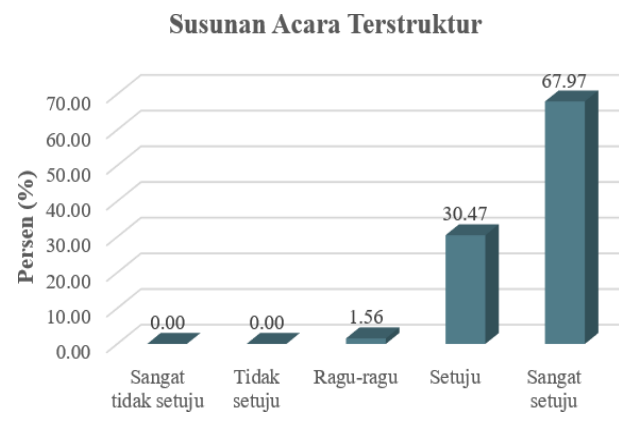

(a)

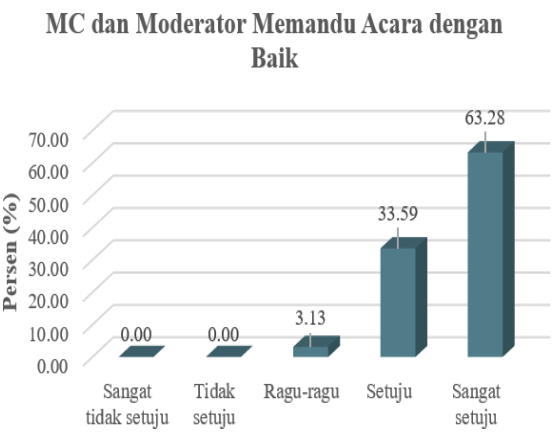

(c)
Pembukaan Acara Dibuka oleh Pimpinan

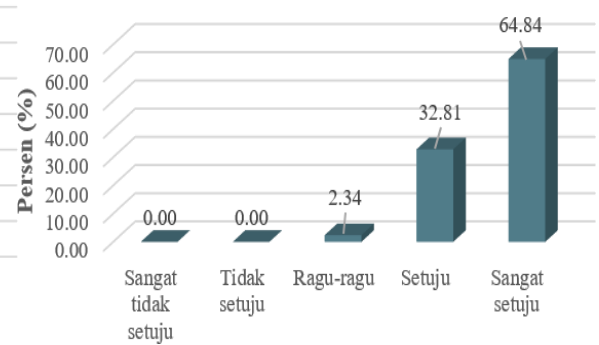

(b)

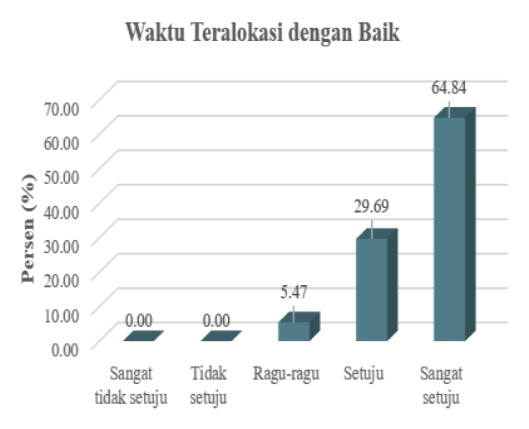

(d)

Gambar 1. (a) Susunan acara terstruktur, (b) Pembukaan acara dibuka oleh pimpinan, (c) Waktu teralokasi dengan baik, (d) MC dan Moderator memandu acara dengan baik. 
Pada gambar tersebut, peserta menilai bahwa MC dan moderator telah memandu kegiatan webinar dengan baik. Hal tersebut, terkonfirmasi dari jumlah peserta/responden di atas $70 \%$ menyatakan setuju dan sangat setuju.

\section{Tema Dan Materi Webinar}

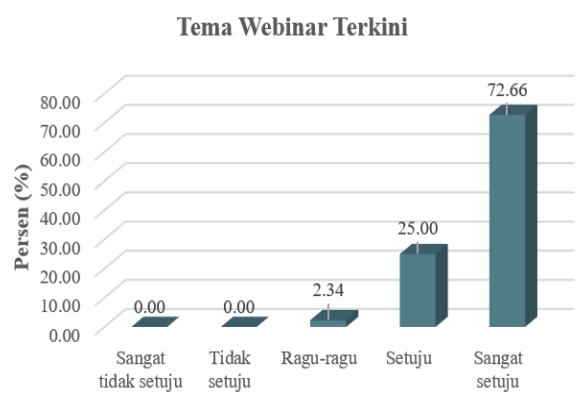

(a)

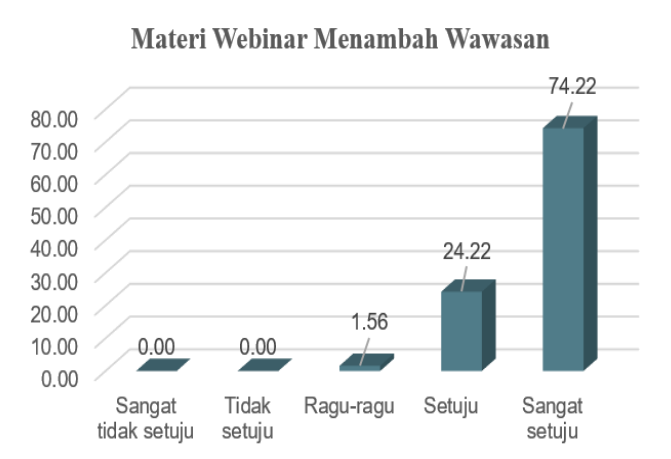

(c)
Komponen penilaian kedua terkait keberhasilan acara webinar yaitu tema dan materi yang diangkat dalam webinar tersebut. Bertepatan dengan hal itu, komponen tersebut akan diilustrasikan pada gambar 2 sebagai berikut:

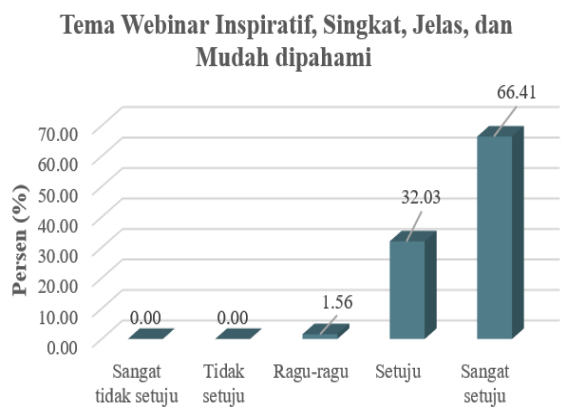

(b)

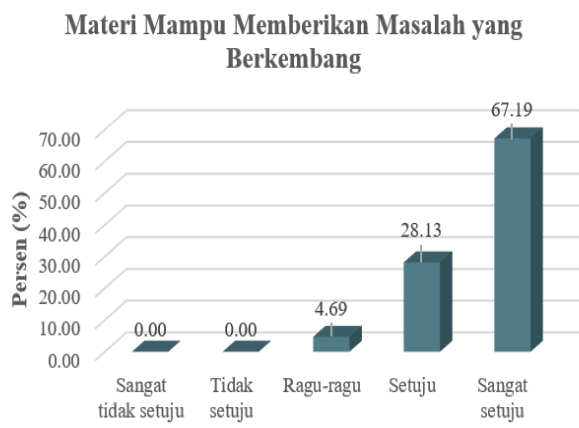

(d)

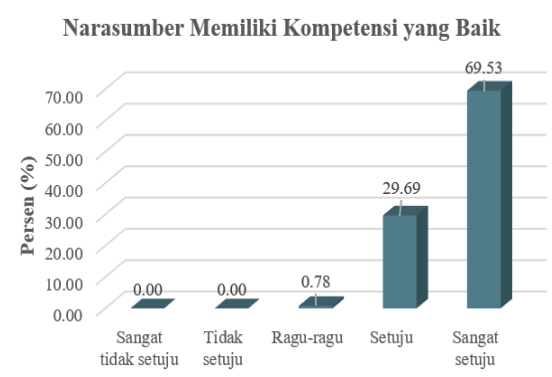

(d)

Gambar 2. (a) Tema webinar terkini, (b) Tema webinar inspiratif, singkat, jelas, dan mudah dipahami, (c) Materi webinar menambah wawasan, (d) Materi webinar memberikan solusi. 
Gambar 2 adalah histogram respon peserta terhadap tema webinar yang disajikan yaitu "Trend Pembelajaran Daring di Era New Normal". Berdasarkan respon tersebut, menyimpulkan bahwa tema dari kegiatan menurut peserta webinar adalah tema yang terkini, inspiratif, singkat, jelas, mudah dipahami, menambah wawasan, dan dapat dijadikan solusi terhadap masalah yang berkembang saat ini. Bertepatan dengan hal itu, responden memberikan penilaian terhadap tema webinar melalui kuisioner dalam bentuk tingkat kepuasan yangmana mayoritas responden tersebut memberikan respon positif (sangat setuju) terhadap tema yang dibawakan.

\section{Narasumber}

Keterkaitan tema dan materi tidak terlepas dari kemampuan presenter atau narasumber yang menyampaikannya. Oleh karena itu, komponen ketiga yang menjadi penilaian adalah narasumber, yang akan diilustrasikan pada gambar 3 di bawah ini:

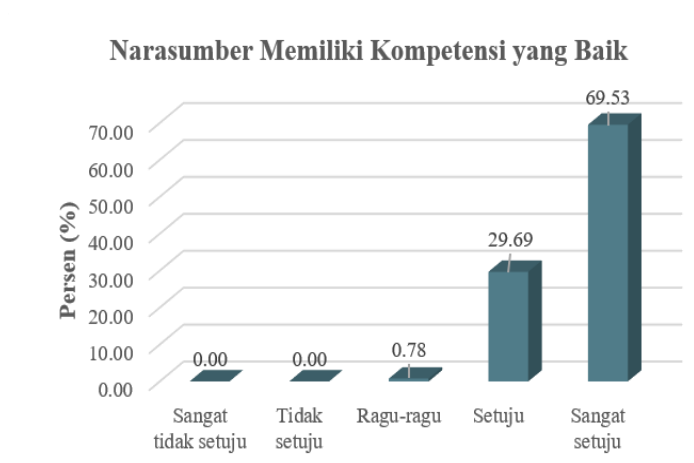

(a)

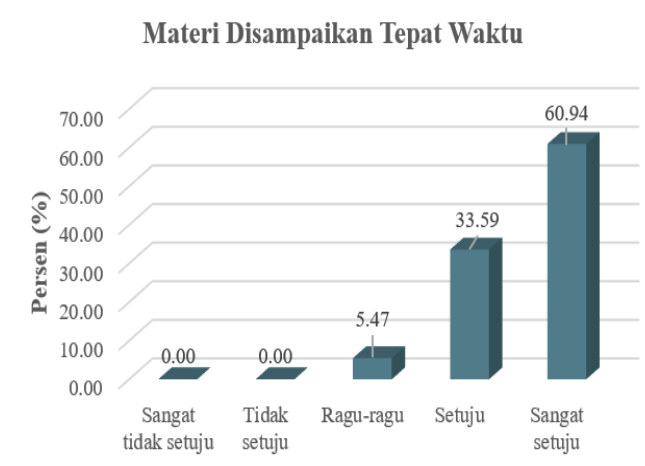

(c)
Materi Disampaikan Secara Lugas dan Jelas

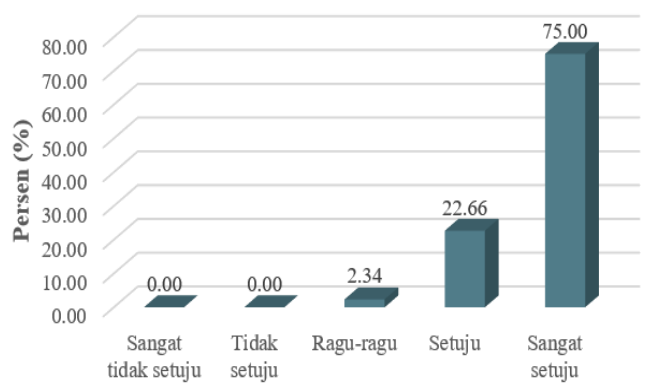

(b)

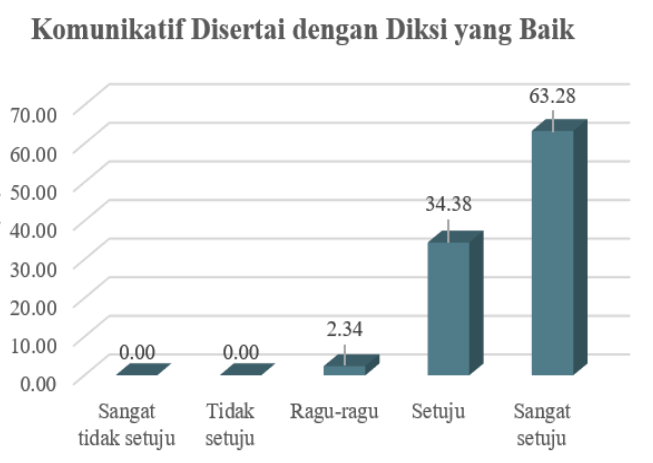

(d) 


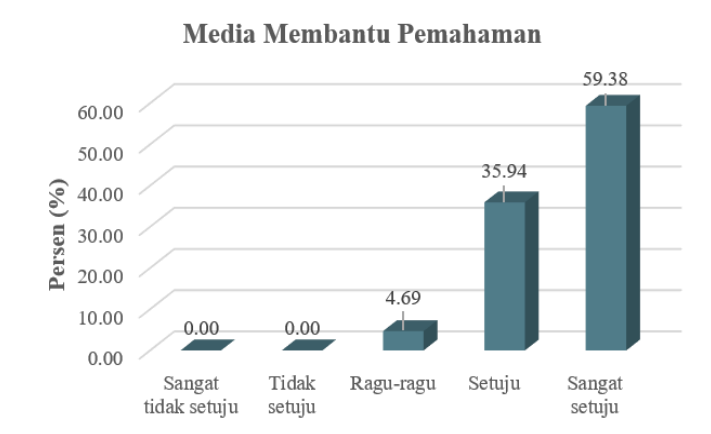

(e)

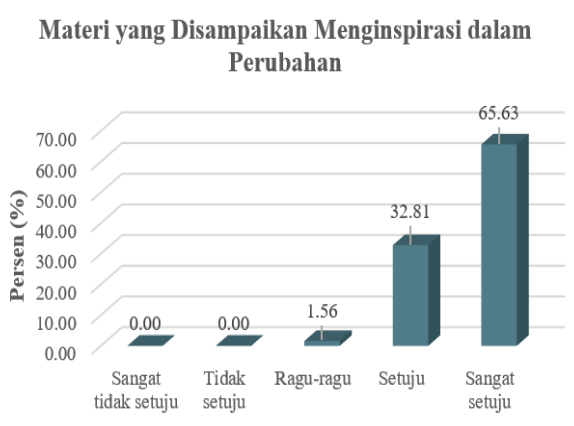

(f)

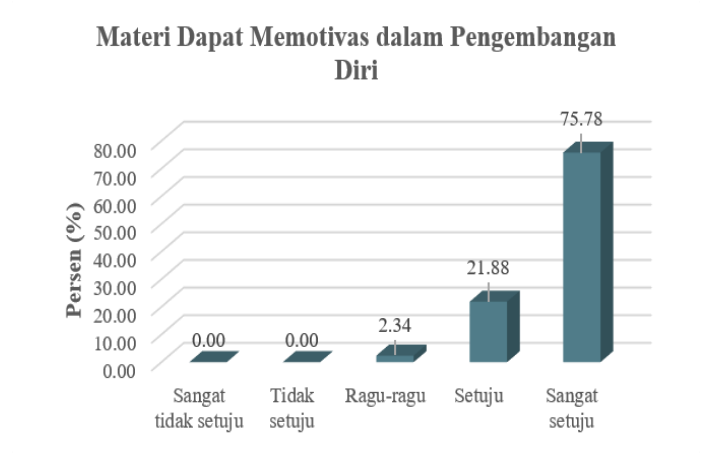

(g)

Gambar 3. (a) Narasumber memiliki kompetensi yang baik, (b) Penyampaian materi oleh narasumber lugas dan jelas, (c) Materi disampaikan tepat waktu, (d) Penyampaian narasumber komunikatif disertai diksi yang baik, (e) Media yang digunakan mampu membantu pemahaman, (f) Memberikan inspirasi untuk perubahan, (g) Memberikan motivasi untuk mengembangkan diri.

Gambar 3 adalah histogram yang merupakan respon dari peserta mengenai narasumber dalam memaparkan materi. Narasumber pertama yaitu yaitu Drs. Yayat W. Herianto, M.M, M,Ikom yang menyampaikan materi mengenai 'Pembelajaran Daring dan Kreativitas Guru' dan narasumber kedua yaitu Prof. Dr. Sarkadi, M.Si yang menyampaikan materi mengenai 'Pembelajaran Daring dan Pembentukan Karakter Siswa'. Dari kedua materi yang disampaikan oleh narasumber, responden memberikan feedback berupa tingkat kepuasan yang mayoritasnya bernilai positif (sangat setuju) terhadap cara penyampaian materi oleh narasumber yang lugas, jelas, komunikatif, dan memotivasi.

\section{Sesi Tanya Jawab}

Komponen keempat yang dijadikan kriteria keberhasilan berlangsungnya acara adalah tersampaikannya materi dengan baik. Komponen tersebut melibatkan kedua belah pihak, yaitu narasumber dan peserta. Untuk memenuhi kriteria tersebut akan diilustasikan pada gambar 4 sebagaiberikut: 


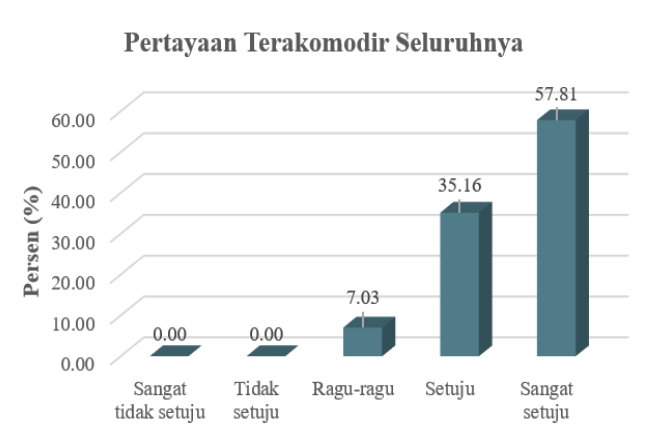

(a)

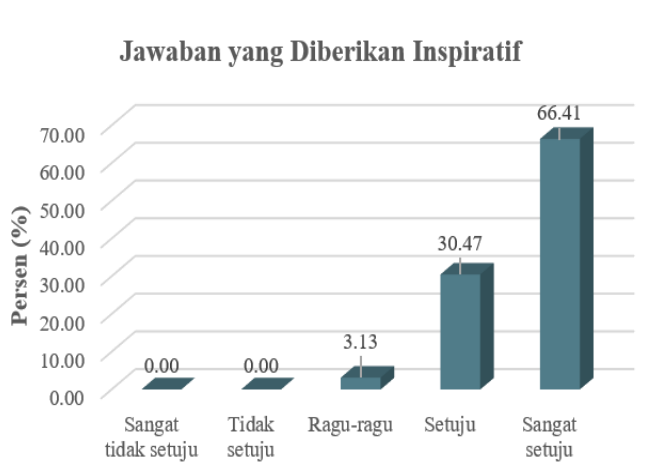

(c)

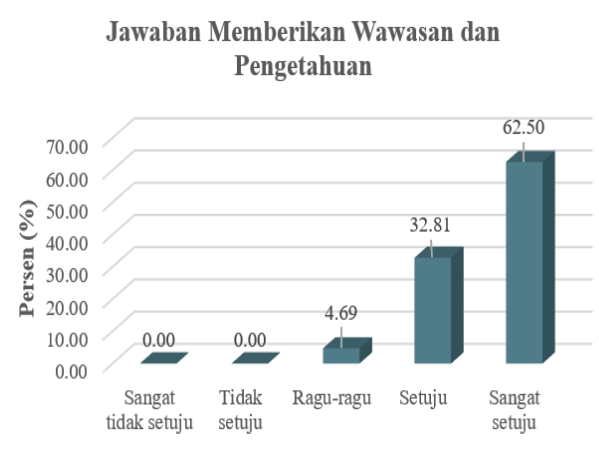

(b)

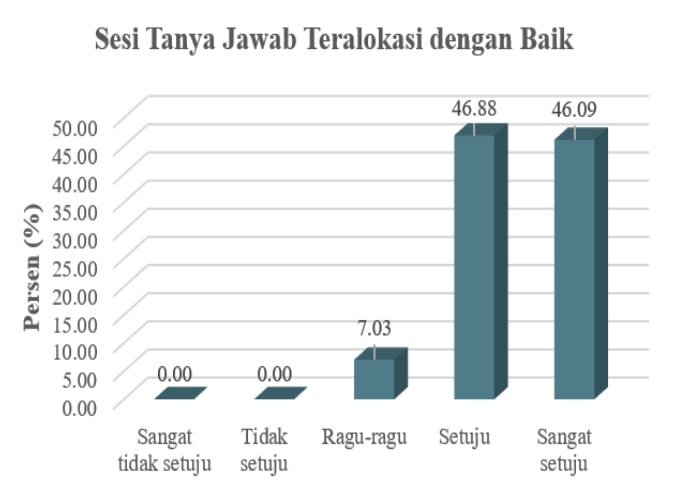

(d)

Gambar 4. (a) Pertanyaan terakomodir seluruhnya, (b) Jawaban memberikan wawasan dan pengetahuan, (c) Webinar inspiratif, (d) Sesi tanya jawab teralokasi dengan baik.

Gambar 4 menunjukkan histogram yang merupakan respon peserta pada sesi tanya jawab selama webinar berlangsung. Pada sesi ini, dilakukan tanya jawab yang diajukan oleh peserta kepada narasumber terkait materi yang disampaikan. Mengacu pada histogram pada gambar 4, mayoritas peserta memberikan penilaian positif (sangat setuju) terhadap berlangsungnya sesi tanya jawab yang terakomodir keseluruhan, jawaban yang memberikan wawasan, pengetahuan, dan inspiratif.

Feedback positif yang diberikan responden terhadap webinar ini tidak terlepas dari peran penting kedua narasumber yang menyajikan materi dengan sangat baik, sehingga dapat membuka dan memperluas cara pandang dan pola pikir para guru dalam meningkatkan kreativitas mengajar dan dalam pembentukan karakter siswa.

Mengutip dari materi yang disampaikan oleh kedua narasumber, bahwa pendidikan karakter dapat diintegrasikan dalam pembelajaran yang berkaitan dengan norma atau nilai-nilai pada setiap mata pelajaran, dieksplisitkan, dikaitkan dengan konteks kehidupan sehari-hari. Pendidikan karakter di sekolah sangat terkait dengan pengelolaan sekolah meliputi, bagaimana pendidikan 
karakter rencanakan, dilaksanakan, dan dikendalikan secara memadai. Pengelolaan tersebut antara lain meliputi, nilai-nilai yang perlu ditanamkan, muatan kurikulum, pembelajaran, penilaian, pendidik dan tenaga kependidikan, dan komponen terkait lainnya (Widiastuti,2012). Terselenggaranya acara webinar pada 14 Agustus 2021 dengan tema "Trend Pembelajaran Daring di Era New Normal" secara keseluruhan dapat dinilai melalui grafik yang telah direpresentasikan diatas. Pada grafik tersebut, mayoritas responden memberikan respon positif (sangat setuju) terhadap acara webinar yang meliputi tema webinar, susunan acara webinar, narasumber yang dihadirkan, dan sesi tanya jawab yang terakomodir dengan baik, inspiratif, memberikan wawasan dan memotivasi. Respon tersebut menandakan acara webinar berlangsung dengan baik.

\section{PENUTUP}

Pandemi Covid-19 memberikan dampak yang signifikan pada bidang pendidikan, khususnya kegiatan belajar mengajar, yang awalnya berlangsung secara konvensional menjadi pembelajaran jarak jauh secara daring. Proses pembelajaran secara daring memberikan kesempatan kepada guru dan siswa untuk mampu belajar dengan cara efektif dan efisien. Namun, dengan pembelajaran secara daring menyebabkan keterbatasan dalam penggunaan teknologi dan mengontrol siswa. Bertepatan dengan hal tersebut, tim KKN kami melaksanakan webinar dengan tema 'Trend Pembelajaran Daring di Era New Normal' sebagai solusi dan jawaban atas permasalahan yang tengah berkembang di masyarakat. Webinar tersebut ternyata mampu mengamati tingkat kepuasan para peserta yang hampir $100 \%$ adalah guru di wilayah DKI Jakarta. Umumnya peserta setuju dengan kreativitas guru dalam pembelajaran mampu membentuk karakter siswa.

\section{Ucapan Terima Kasih}

Terima kasih kami ucapkan kepada Lembaga Penelitian dan Pengabdian kepada Masyarakat (LPPM) Universitas Negeri Jakarta melalui Hibah Pengabdian kepada Masyarakat Terintegrasi KKN No. 18/PPMKKN/LPPM/IV/2021.

\section{DAFTAR PUSTAKA}

Hartati Widiastuti. (2012). Peran Guru Dalam Membentuk Siswa Berkarakter. Universitas Muhammadiyah Surakarta: Program Studi PGSD FKIP.

Hatip, Ahmad. (2020). The Transformation of Learning During Covid-19 Pandemic Towards The New Normal Era. Proceding "International Webinar On Education 2020."

Pentury, H. J. (2017). Pengembangan

Kreativitas Guru dalam

Pembelajaran Kreatif

Pembelajaran Bahasa Inggris. Jurnal Ilmu Kependidikan, 4(3), 265-272.

Siagian, Tiodora Hadumaon. (2020). 
Mencari Kelompok Berisiko Tinggi Terifeksi Virus Corona Dengan Discourse Network Analysis. Jurnal Kebijakan Kesehatan Indonesia: JKKI, Vol. 09, No. 02, hal 98-106.

Sulistyorini dan Fathurrohman M. (2016). Esensi Manajemen Pendidikan Islam :Pengelolaan Lembaga untuk Meningkatkan Kualitas Pendidikan Islam. Yogyakarta. Kalimedia Syariffudin,A.S. (2020). Implementasi Pembelajaran Daring Untuk Meningkatkan Mutu Pendidikan
Sebagai Dampak Diterapkannya Social Distancing. Jurnal Pendidikan Bahasa dan Sastra Indonesia Metalingua, 5(1),31-34. Unicef. (2020).Covid-19 dan Anak-anak di Indonesia Agenda Tindakan Untuk Mengatasi Tantangan Sosial Ekonomi. Diakses tanggal 3 Agustus 2020. (https://www.Unicef.org/Indonesi a/ Sites/Unicef.org.Indonesia/Files/2 02 0-05/COVID-19-Dan-AnakAnak- Di-Indonesia-2020_1.Pdf ) 